\title{
Revision of rock fossils of Dryinidae and Embolemidae (Hymenoptera: Chrysidoidea)
}

\author{
MASSIMO OLMI ${ }^{1}$, ALEXANDER P. RASNITSYN $^{2}$ \& ADALGISA GUGLIELMINO ${ }^{1}$ \\ ${ }^{1}$ Department of Plant Protection, University of Tuscia, Viterbo, Italy \\ ${ }^{2}$ A. A. Borissiak Paleontological Institute, Academy of Sciences, Moscow, Russia and Natural History Museum, London, UK
}

\begin{abstract}
New fossil taxa of Embolemidae and Dryinidae (Hymenoptera: Chrysidoidea) are described. For Embolemidae, Embolemopsis baissensis n. gen. n. sp. and Baissobius minutus n. sp., are described from Central Siberia, West Transbaikalia, left bank of Vitim River (facing downstream), Baissa, lake deposits from earlier Early Cretaceous (Neocomian stage) (130-140 mybp). For Dryinidae, Anteonopsis antiquus n. gen. n. sp., Bocchus ? cenomanianus n. sp. and Gonatopus ? cretacicus n. sp., are described from Siberia, Magadan Region, Obeschchayushchiyi, tuffaceous deposits from Upper Cretaceous (Cenomanian) (90-95 mybp); Deinodryinus ? aptianus n. sp., is described from Central Mongolia, Bayanhongor Aimag, 5-8 Km N Bon Tsagan Nuur Lake, from impressed in lake deposits of the Khurilt rock unit probably of Aptian (Early Cretaceous) (100-115 mybp). In addition, an unidentified fossil belonging to Deinodryinus? or Dryinus? is recorded from Russian Far East, Maritime Province, Velikaya Kema (later Earlier or early Middle Miocene) (about 30 mybp). The known species of Baissobius Rasnitsyn are reviewed and a key is presented.
\end{abstract}

Key words: new fossil taxa, Cretaceous, Tertiary, Mongolia, Siberia

\section{Introduction}

Fossil Embolemidae (Hymenoptera: Chrysidoidea) are known from both the Cenozoic and the Cretaceous from amber (Brothers \& Rasnitsyn, 2003; Olmi, 1995; Rasnitsyn \& Matveev, 1989) and from marl (Rasnitsyn, 1975, 1996). Fossil Dryinidae (Hymenoptera: Chrysidoidea), however, are known exclusively from both Cenozoic and Cretaceous amber (Engel, 2003; Olmi, 2005; Olmi \& Bechly, 2001; Peinado et al., 2006; Ponomarenko N., 1975, 1981, 1988; Rasnitsyn \& Kulicka, 1990; Zherikhin et al., 2009) from the following zoogeographical regions: Palaearctic (Baltic, Oise, Lebanese and Taimyr amber), Nearctic (Medicine Hat amber), Neotropical (Dominican Republic and Chiapas amber) and Oriental (Burmese amber).

For the most part, Dryinidae and Embolemidae fossils from the Tertiary show only specific differences with extant species, because many genera of this period are extant. On the contrary, fossils of these two families from Cretaceous should be very important, because of the possible presence of extinct supraspecific taxa.

In recent years, we have studied some new fossils of the above families from various rocks of Mongolia and Siberia, deposited in the A. A. Borissiak Paleontological Institute, Russian Academy of Sciences. This study is resulted in the discovery of new genera and new species described as follows.

\section{Material and methods}

The descriptions follow the terminology used by Olmi $(1984,1994,1999)$. The measurements reported are relative, except for the total length (head to abdominal tip, without the antennae) and the length of some parts of the body, which are expressed in millimetres. 